УДК 94(477.8):355“1948”

DOI:

Олександра Свйонтик, кандидат педагогічних наук, дочент кафедри загальної педагогіки та дошкільної освіти Дрогобииького державного педагогічного університету імені Івана Франка Микола Галів, доктор педагогічних наук, дочент кафедри історії Украӥни Дрогобищького державного педагогічного університету імені Івана Франка

\title{
ДОКУМЕНТ З ІСТОРІЇ ПОВСЯКДЕННОГО ЖИТТЯ ЧЕРНІВЕЦЬКОГО ДЕРЖАВНОГО УЧИТЕЛЬСЬКОГО ІНСТИТУТУ (1948 р.): АРХЕОГРАФІЧНИЙ АНАЛІЗ
}

У статті з дотримання сучасних археографічних вимог проаналізовано й опубліковано документ “Відомості з Державного Учительського Інституту в м. Чернівиях”, датований листопадом 1948 р. У ньому представлена агентурна інформачія, здобута учасниками українського підпілля в Чернівиях від своїх агентів - студентів місиевого учительського інституту. Документ умовно поділено на п'ять частин, в яких в основному змальовано складні національні відносини між студентами - росіянами і украйнцями на мовнолітературному факультеті зазначеного вищу. Водночас документ не позбавлений слабких сторін “авторського джерела”: суб'єктивності, осудливих оцінок, упереджень, надмірних узагальнень тощо. Вважаємо "Відомості з Держсавного Учительського Інституту в м. Чернівиях" важливим репрезентативним історичним джерелом до історії повсякденного життя студентства другої половини 1940-х рр. у Чернівиях зокрема, та у західноукраӥнських областях України загалом.

Ключові слова: Чернівецький державний учительський інститут; повсякденне життя; ОУН; комсомол; міжнаціональні антагонізми.

Jim. 12.

Oleksandra Sviontyk, Ph.D.(Pedagogy), Associate Professor of the General Pedagogy and Preschool Education Department Drohobych Ivan Franko State Pedagogical University Mykola Haliv, Doctor of Sciences (Pedagogy), Associate Professor of the History of Ukraine Department Drohobych Ivan Franko State Pedagogical University

\section{DOCUMENT ON THE HISTORY OF EVERYDAY LIFE OF THE CHERNIVTSI STATE TEACHERSJ TRAINING INSTITUTE (1948): ARCHAEOGRAPHICALANALYSIS}

The document "Information from the State Teachersj Training Institute in Chernivtsi", dated November 1948 is analyzes and publishes in this article. It presents intelligent information obtained by members of the Ukrainian underground in Chernivtsi from their agents - students of the local teachers' institute. The document is conditionally divided into five parts, which mainly depict the complex national relations between students - Russians and Ukrainians at the Faculty of Linguistics and Literature of this Institute. At the same time, the document is not without the weaknesses of the "author's source": subjectivity, reprehensible assessments, prejudices, excessive generalizations, etc.

According to the authors of the article, the document perfectly demonstrates the existence of national inequality between Russians and Ukrainians, which was tolerated and therefore supported by the official authorities. Readers are presented with a plot, to some extent, of colonial reality, in which the Russian conquerors considered themselves masters of Ukrainian land and treated the local population, its culture, language, and customs with contempt. The privileged position of Russian students was clearly manifested in the overestimation of their grades during their studies for further scholarships, in the unwillingness to work in the subsidiary farm of the institute, which forced Ukrainian students.

We consider "Information from the State Teachers' Training Institute in Chernivtsi" an important and representative historical source for the history of everyday life of students in the second half of the 1940s in Chernivtsi in particular, and in western Ukraine in general. The document is published in the original language in compliance with the necessary archeographic requirements.

Keywords: Chernivtsi State Teachers' Training Institute; everyday life; OUN; Komsomol; interethnic antagonisms.

П остановка проблеми. Дослідження розвитку української вищої педагогічної освіти є одним із першочергових завдань

сучасної історико-педагогічної науки. Попри наявність окремих узагальнювальних праць у цій царині (В. Майборода, О. Лук'яненко), історія 


\section{ДОКУМЕНТ З ІСТОРІЇ ПОВСЯКДЕННОГОЖИТТЯ ЧЕРНІВЕЦЬКОГО ДЕРЖАВНОГО УЧИТЕЛЬСЬКОГО ІНСТИТУТУ (1948 р.): АРХЕОГРАФІЧНИЙ АНАЛІЗ}

окремих закладів вищої освіти потребує уточнення, доопрацювання, збагачення новими документальними матеріалами. Відзначимо, що дослідження історії освітніх інституцій часто мають характер нарисів 3 розвитку структури закладів, реформування змісту освіти, якісного і кількісного зростання викладацького контингенту та студентського колективу. Однак сучасні вимоги у річищі “тотальної історії” вимагають від дослідників, зокрема істориків педагогіки, враховувати усі без винятку аспекти життя закладів освіти, зокрема його внутрішнього середовища, системи відносин, конфліктів, комунікацій, ідей і поглядів (і не лише політичних, педагогічних) учасників освітнього процесу. Зважаючи на це, доречно включати до наукового обігу й документи, які демонструють “з середини” життя академічних колективів українських педагогічних вишів. Саме тому автори статті опрацювали і публікують документ до історії повсякденного життя студентів і викладачів Чернівецького державного учительського інституту кінця 1940-х рp.

Аналіз останніх досліджень і публікацій. Розвиток вищої педагогічної освіти в Україні у радянський період iï історії досліджено у монографії В. Майбороди (1991) [7]. Цікавий і грунтовний аналіз повсякденного життя педагогічних вишів України 1920-1960- х рр. здійснив О. Лук'яненко (2019) [6]. У канві історіографії, безумовно, слід назвати й праці, присвячені історії Чернівецького університету: I. Кобилянського (1975) [4], Т. Марусик (2013) [9], колективні праці сучасних вчених [11; 12]. Відзначимо й колективну монографію “Вища педагогічна освіта і наука України: історія, сьогодення та перспективи розвитку. Чернівецька область" (2011) [2]. Низку наукових праць присвячено студентству західноукраїнських земель перших повоєнних років, в яких згадано і становище молоді у Чернівцях $[5 ; 8 ; 10]$. До нашого часу дійшли спогади репресованих студентів чернівецьких закладів освіти [3]. Відзначимо, що у жодній із зазначених праць не використано документ, який пропонується до розгляду у цій статті.

Мета статті-проаналізувати та опублікувати документ до історії повсякденного життя студентів Чернівецького державного учительського інституту (згодом-університету) наприкінці 1940-х рр.

Виклад основного матеріалу. Аналізований документ має назву "Відомості з Державного Учительського Інституту в м. Чернівцях" i зберігається в Архіві Центру досліджень визвольного руху (Інститут українознавства ім. I. П. Крип’якевича НАН України (м. Львів), фонд
63, том 8 (без пагінації). Цей україномовний машинописний документ складається усього 3 двох сторінок тексту і датований листопадом 1948 р. На другій сторінці наявне незначне фізичне пошкодження паперу, що не дає змоги відтворити частину тексту. Він становить зведене зібрання структурами Українського визвольного руху (насамперед Організації українських націоналістів) агентурних відомостей $з$ життя студентів і викладачів Чернівецького педагогічного вишу за період з вересня до листопада 1948 р. Вочевидь, автором відомостей був підпільник ОУН, який відповідав за роботу з агентурою та збирав необхідну інформацію 3 терен Чернівців для подальшої передачі іiї своїм керівникам. На жаль, не видається можливим назвати прізвище автора.

Звісно, документ сформований на основі інформації, зібраної з різних агентурних джерел. Однак більшість даних надійшла від однієї особи, яка добре знала події в Чернівецькому державному учительському інституті й навіть була присутньою на деяких заходах, зокрема на зустрічі дирекції інституту зі студентством, про що залишила детальну інформацію, наводячи навіть цитати. Припускаємо, що ця особа була агентом ОУН, який вступив на мовнолітературний факультет інституту, а саме на його український відділ. До цього висновку підштовхує сам зміст документа, в якому здебільшого йдеться про ситуацію у цьому структурному підрозділі Чернівецького вишу.

Беручи до уваги семантико-змістові компоненти документа, наведену у ньому текстову інформацію можна поділити на п’ять частин. У першій - вступній - частині подано загальну інформацію про російський та український відділи мовно-літературного факультету Чернівецького державного учительського інституту, показано національний склад студентів, причому щодо російського відділу - у відсоткових показниках (40\% росіян, $40 \%$ євреїв та $20 \%$ українців). Згадано й про розмір стипендії для студентів російського відділу - 350 крб/міс. Водночас у першій частині задекларовано одну 3 основних тематичних ліній джерела: наявність національних антагонізмів між студентами i викладачами - росіянами та українцями. Автор документа обвинувачує російський студентів i викладачів у шовінізмі, зневажливому ставленні до української мови і культури, намаганні переконати українських студентів, зокрема й вихідців зі східних областей України, у залежному становищі українською культури від російської тощо. Серед таких викладачів названо двох осіб: старшого викладача психології Красногорського 


\section{ДОКУМЕНТ З ІСТОРІЇ ПОВСЯКДЕННОГО ЖИТТЯ ЧЕРНІВЕЦЬКОГО ДЕРЖАВНОГО УЧИТЕЛЬСЬКОГО ІНСТИТУТУ (1948 р.): АРХЕОГРАФІЧНИЙ АНАЛІЗ}

та викладачку російської мови Берту Калінську. Відзначимо, що у цій частині виявляються й певні погляди автора на такі теорії, оскільки він прямо називає їх “перекручування" правди та “псевдонауковими твердженнями різних російських лжеучених-шовіністів” $[1,1]$.

Друга частина документа логічно пов’язана 3 першою, але містить здебільшого опис однієї конкретної події-звернення дирекції інституту до студентів щодо припинення національної ворожнечі. Цьому опису передує констатувальний вступ про наявність між студентами російського та українського відділів “сильної національної ворожнечі”. Проявом останньої, за словами автора джерела, є не просто зверхнє ставлення росіян до українців, але й образливі висловлювання на їхню адресу, репрезентовані політичного ідеологічними вульгаризмами сталінських часів: “куркулі”, “бандери”, “фашисти”, “буржуазні шпигуни”. Відтак подальший текст містить опис певного зібрання, скликаного 3 приводу необхідності врегулювання національного конфлікту поміж студентами. На жаль, у документів не вказано формат зібрання, але припускаємо, що, можливо, йдеться про комсомольські збори, на яких була присутня дирекція інституту. Автор подає низку запитань, які начебто висловили українські студентикомсомольці зі східних терен України: “Чому класні керівники та викладачі російського відділу сіють і культивують національну нетерпимість? Чому викладачі російського відділу підбурюють студентів проти студентів з українського відділу? Чому російські студенти, які не заслуговують на гарні оцінки в навчанні, мають на папері кращі оцінки? Чому студенти з російського відділу не працюють у вихідні дні на підсобному господарстві, як це змушені робити студенти 3 українського відділу? Якщо студенти 3 російського відділу не ходять працювати, то хай хоч не насміхаються 3 нас як з чорних робочих, колгоспників, хахлів та бандерівців" $[1,1]$. Автор документа вказав на непереконливу позицію дирекції у цьому питанні, сповнену декларативних закликів щодо “прав народів” у Радянському Союзі та непотрібності непорозумінь, образ, насмішок поміж студентами.

Третя частина документа - це опис окремих випадків $з$ життя студентства інститут восени 1948 р., який було доручено сформувати пожежну команду, забезпечити будинок інституту піском та водою на випадок пожежі. Автор вказав на причину таких приготувань - побоювання початку війни проти СРСР. Водночас у цій частині описано щопонеділкові політзаняття викладача
Красногурського, які, за словами автора, не цікавлять студентів, оскільки не мають нічого спільного з висвітленням дійсного стану речей. Один із абзаців документа присвячено і репресіям органів Міністерства державної безпеки щодо студентів інститут. На жаль, пошкоджений текст джерела не дає змоги встановити кількість заарештованих студентів, читабельною $є$ лише згадка про вісім заарештованих студентів“східняків". Зауважимо, що йдеться про вересень - листопад 1948 р., тож така кількість арештів серед студентства одного закладу освіти за кілька місяців $є$ доволі значною і показовою.

Четверта частина документа присвячена комсомольській організації студентів, куди останніх “примушують на кожному кроці вступати”. Подано навіть короткий діалог між студентом і комсоргом про якість такої роботи. Надалі автор намагається показати незадовільне “моральне обличчя" комсомольців, зображаючи їх розпусниками, п'яницями, грубіянами, злодіями $[1,2]$. Відчутним $\epsilon$ вкрай негативне ставлення автора до “перевихованих" за радянським взірцем молодих людей - членів ВЛКСМ.

Остаття - П'ята - частина документа містить позитивну характеристику взаємин між українськими студентами-вихідцями зі східних і західноукраїнських земель $[1,2]$. Вочевидь, вони надто обнадійливі (особливо у тезах про “ненависть до партії і уряду”, “відсіч російському шовінізмові”) й покликані показати всеукраїнську єдність молоді перед лицем радянського тоталітаризму. Хоча не виключаємо й того, що серед студентів справді було чимало осіб, які ставилися критично до політики радянських властей i більшовицької партії, читали “революційну” (націоналістичну) літературу, не бажали приєднуватися до комсомолу.

Загалом документ містить важливу інформацію про наявність складних міжнаціональних взаємин поміж студентам Чернівецького державного учительського інституту. Він прекрасно демонструє наявність національної нерівності між росіянами та українцями, толерованої, а отже, i підтримуваної офіційними властями. Перед нами постає сюжет, до певної міри, колоніальної дійсності, в якому росіяни-завойовники вважали себе господарями на українській землі i зневажливо ставляться до місцевого населення, його культури, мови, звичаїв. Привілейоване становище студентів-росіян яскраво виявлялося у завищених оцінках їх навчальної успішності задля отримання ними стипендій, у небажані працювати в підсобному господарстві інституту, до чого змушували студентів-українців. 3 іншого 


\section{ДОКУМЕНТ З ІСТОРІЇПОВСЯКДЕННОГОЖИТТЯ ЧЕРНІВЕЦЬКОГО ДЕРЖАВНОГО УЧИТЕЛЬСЬКОГО ІНСТИТУТУ (1948 p.): АРХЕОГРАФІЧНИЙ АНАЛІЗ}

боку, не слід беззастережно сприймати емоційні оцінки автора джерела, який відверто осудливо ставився до росіян, більшовиків, комсомольців, використовував політичні і національні штампи, давав надміру узагальнені й однозначно негативні оцінки російським студентам-комсомольцям.

Висновки. Отже, публікований документ “Відомості 3 Державного Учительського Інституту в м. Чернівцях" датований листопадом 1948 р. У ньому представлена агентурна інформація, здобута учасниками українського підпілля в Чернівцях від своїх агентів - студентів місцевого учительського інституту. Документ умовно складається 3 п'яти частин, наскрізною лінією в якому $є$ змалювання складних, антагоністичних національних відносин між студентами - росіянами і українцями на мовнолітературному факультеті зазначеного вишу. Водночас документ не позбавлений слабких сторін “авторського джерела”: суб’єктивності, осудливих оцінок, упереджень, надмірних узагальнень тощо. Вважаємо "Відомості з Державного Учительського Інститутув м. Чернівцях" важливим і репрезентативним історичним джерелом до історії повсякденного життя студентства другої половини 1940-х рр. у Чернівцях зокрема, та у західноукраїнських областях України загалом. Документ публікується мовою оригіналу з дотриманням необхідних археографічних вимог.

\section{ВІДОМОСТІ}

3 Державного Учительського Інституту в м. Чернівцях

У Чернівецькому Держ[авному] Учит[ельському] Інституті є два відділи мовно-літературного факультету, а саме: український та російський. Від початку навчального року 1948 [...] помічено тут великий антагонізм між росіянами і українцями / викладачами та студентами/. Росіяни намагаються на кожному уроці понижувати студентів-українців, а в тому особливо студентів-українців із СУЗ. На Українському відділі студіюють лише українці / за виїмком двох польок/, з чого більш як половину становлять східняки. На Російському відділі є 40 \% росіян, $40 \%$ жидів та $20 \%$ українців /майже всі комсомольці/ зі СУЗ. На російському відділі майже всі студенти одержують стипендії /другого і третього ступеня/ у висоті 350 і 450 крб. /остання це т.зв. сталінська премія/. В тій цілі викладачі / російські шовіністи/ штучно ви двигають та підвищують студентам-росіянам оцінки 3 успішности. Це викликає велике обурення серед студентів з українського відділу. Своє негодування особливо гостро виявляють студенти-східняки, які належать до комсомолу. Часто трапляються випадки, що студенти зі СУЗ та ЗУЗ домагаються від викладачів, щоб вони викладали українською мовою. Але викладачі-росіяни не звертають уваги на домагання студентів і викладають дальше російською мовою. Один викладач-москвич дуже поденерувавшись одного разу, викрикував: “Я викладаю і викладатиму тільки російською мовою тому, бо це мова передова, культурна, це - мова Леніна-Сталіна. На викладах викладачі намагаються при кожній нагоді впоювати студентам українського відділу большевицький шовінізм, поняття про вищість російської мови і культури, переконання про правильність внутрішньої і зовнішньої політики. Вони завжди, при кожній найменшій нагоді блеють про походження і залежність української мови і культури від російської, перекручуючи в наївний $\mathrm{i}$ примітивний спосіб правду та покликаючись на різні псевдонаукові твердження різних російських лжеучених-шовіністів. Особливо активним у цьому відношення є москаль Красногорський / старший викладач по психольогії, українець, партійний/ та Калінська Берта /викладачка російської мови, жидівка, партійна/. Їх студенти прозвали недобитками та дочасниками.

Між студентами російського і українського відділу існує сильна національна ворожнеча. Одною з причин є те, що викладачі та студенти російського відділу вважають студентів українського відділу за щось нижче, некультурне та часто-густо насміхаються з української мови, культури, поведінки студентів і т.ін. Дуже часто можна почути від них такі вислови, як: кулаки, бандери, фашисти, буржуазні шпигуни і т. п.

Одного разу появилося звернення дирекції, щоби припинити, а в парі з тим розглянути причини національної ворожнечі, що почала прибирати чимраз та більші розміри. Після появи звернення класні керівники почали проводити просто формальні слідства. Але окремі студентикомсомольці зі СУЗ виступили з протестами, заявляючи з обуренням: “Чому класні керівники та викладачі російського відділу сіють i культивують національну нетерпимість? Чому викладачі російського відділу підбурюють студентів проти студентів з українського відділу? Чому російські студенти, які не заслуговують на гарні оцінки в навчанні, мають на папері кращі оцінки? Чому студенти з російського відділу не працюють у вихідні дні на підсобному господарстві, як це змушені робити студенти 3 українського відділу? Якщо студенти 3 російського відділу не ходять працювати, то хай хоч не насміхаються 3 нас як 3 чорних робочих, 


\section{ДОКУМЕНТ З ІСТОРІЇ ПОВСЯКДЕННОГО ЖИТТЯ ЧЕРНІВЕЦЬКОГО ДЕРЖАВНОГО УЧИТЕЛЬСЬКОГО ІНСТИТУТУ (1948 р.): АРХЕОГРАФІЧНИЙ АНАЛІЗ}

колгоспників, хахлів та бандерівців”. Коли східняки скінчили говорити, решта студентів заявили одноголосно “Правильно! Правильно!”. Дирекція дала на те невичерпну відповідь, намагаючись оборонити студентів-росіян, запевняючи, що ніби росіяни заслуговують на кращі оцінки, а до роботи на підсобне господарство [...] будуть ходити. Коли йде про інші закиди, то дирекція [...] непорозумінь не повинно бути і що студенти [...] не повинні насміхатись чи образливо висловлюватися [...]. Наприкінці директор звернув увагу [... розводячись широко про права народів в СССР.

На початку вересня доручено студентам українського і російського відділів алярмово виловити 3-поміж себе пожарну команду та забезпечити будинок інституту піском, водою та $[\ldots]$. Коли студенти запитували, чому це все мають зробити так алярмово, їм відповіли, що днями може вибухнути війна.

Кожного понеділка відбуваються політзаняття, які найчастіше переводить згаданий вище Красногорський. Отсі доповіді він [...] завжди на товстих матеріалах. Студенти 3 політзанять тікають додому. Кожний із них заявляє, що брав би участь у політзаняттях, коли б на них говорили про дійсний стан речей, про те, що дійсно відбувається у світі, або хоч про війну, але коли говорять завжди те саме, то це їх нудить.

Час від час МГБ арештує студентів з інституту, технікуму, серед [ніх шкіл] [...], не оминаючи при тому східняків. На протязі дох місяців безпідставно [...] студентів /в тому вісім східняків/ за підривну антирадянську роботу серед студентів. У школах діє на досить велику скалю агентура, сіючи взаємне недовірјя серед студентів.

Студентів примушують на кожному кроці вступати до комсомолу. Існує клич, що хто не комсомолець, той не радянська людина, це хахол, бандера та ворог Радянського Союзу. Один студент східняк сказав комсоргові: “Керівні чинники комсомольської організації втягують до комсомолу силою тих студентів, які добровільно нізащо до нього не вступили б. На мою думку це тільки кількість, але якості немає”. Комсорг відповів: “Це не твоє діло! Ти краще мовчи!".

Коли йде про мораль, то треба сказати, що їі майже немає. Студенти-комсомольці - це люди “перевиховані”. Полові зносини серед них - явище загальне і буденне. Розпуста сягає шалених розмірів, особливо між “перевихованими”. Серед них багато венерично хворих пияків та хуліганів. До великих розмірів та майстерности дійшло злодійство i то виключно серед цих “перевихованих". Серед студентів російського відділу та серед деяких з українського завважується страшне грубіянство, вульгаризм. Нецензурними словами послуговуються в однаковій мірі [...] і жінки. Студенти гуляють 3 викладачами і навпаки. "Перевиховані” завжди говорять: “Ми, значить студенти, повинні жити по радянському..., а не по буржуазному”.

Між деякими студентами зі СУЗ та ЗУЗ на українському відділі існують дружні відносини і співпраця. Ці студенти завжди сприймають виклади критично, добре розуміють брехливу і фальшиву політику большовиків. Час від часу вони читають нашу революційну літературу, симпатизують 3 українським повстанчим рухом, а в парі $з$ цим проявляють велику ненависть до партії і уряду, дають належну відсіч російському шовінізмові, ставлять опір комсомолові i протиставляться його впливові.

Листопад, 1948 р.

Джерело: Архів Центру досліджень визвольного руху. Ф. 63, Т. 8 (без пагінації).

\section{ЛІТЕРАТУРА}

1. Архів Центру досліджень визвольного руху. Ф. 63, Т. 8 (без пагінаціі).

2. Вища педагогічна освіта і наука України: історія, сьогодення та перспективи розвитку. Чернівецька область. Київ: Знання України, 2011. 279 c.

3. 3 аудиторії за колючі дроти. Спогади студентів чернівецьких вузів, репресованих тоталітарною системою / Упор.: С.Далавурак, В.Фольварочний. Чернівці: Рута, 1995. 164 с.

4. Кобилянський I. Чернівецький Університет. Ужгород, 1975. $66 \mathrm{c}$.

5. Ковалюк Р. Український студентський рух на західних землях XIX - XX ст. Львів, 2001. 420 с.

6. Лук'яненко О. “Найближчі друзі партіі”: колективи педагогічних вишів України в образах щодення 1920-х - першої половини 1960-х років. Полтава: Видавництво “Сімон”, 2019. 658 с.

7. Майборода В. К. Вища педагогічна освіта в Україні : історія, досвід, уроки (1917-1985 рр.). Київ: Либідь, 1992. 196 с.

8. Марусик Т. В. Студентство Буковини під тиском сталінських репресій (1945 - 1950-ті роки). 3 архівів ВУЧК-ГПУ-НКВД-КГБ. Київ, 1999. № 1/2 (10/11). C. 457-468.

9. Марусик Т. Чернівецький національний університет ім. Ю. Федьковича. Енциклопедія історії Украӥни: у 10 т. Київ. 2003. Т. 10. С. 502.

10. Хоменко Н.М. Деякі аспекти політичних настроїв повоєнного студентства України. Наукові записки Вінницького державного педагогічного університету імені Михайла 
Кочџюбинського. Серія: Історія. 2010. Вип. 17. C. $85-91$.

11. Чернівецький національний університет імені Юрія Федьковича. Імена славних учасників. Довідково-біографічне видання. Упорядники: Неоніла Струк, Олена Матвійчук. Київ: Світ успіху, 2005. $145 \mathrm{c}$.

12. Чернівецький університет. 1875-1995. Сторінки історії. Чернівці: Рута, 1995. 116 с.

\section{REFERENCES}

1. Arkhiv Tsentru doslidzhen vyzvolnoho rukhu [Archive of the Center for Liberation Movement Studies], found 63, vol. 8. [in Ukrainian].

2. Vyshcha pedahohichna osvita i nauka Ukrainy: istoriia, sohodennia ta perspektyvy rozvytku. Chernivetska oblast (2011). [Higher pedagogical education and science of Ukraine: history, present and prospects of development. Chernivtsi region]. Kyiv, 279 p. [in Ukrainian].

3. Dalavurak, S. \& Folvarochnyi, V. (1995). Z audytorii za koliuchi droty. Spohady studentiv chernivetskykh vuziv, represovanykh totalitarnoiu systemoiu [From the audience for barbed wire. Memoirs of students of Chernivtsi universities repressed by the totalitarian system]. Chernivtsi, $164 \mathrm{p}$. [in Ukrainian].

4. Kobylianskyi, I. (1975). Chernivetskyi Universytet [Chernivtsi University]. Uzhhorod, 66 p. [in Ukrainian].

5. Kovaliuk, R. (2001). Ukrainskyi studentskyi rukh na zakhidnykh zemliakh XIX- XX stolittia [Ukrainian student movement in the western lands of the XIX - XX centuries]. Lviv, 420 p. [in Ukrainian].

6. Lukianenko, O. (2019). "Naiblyzhchi druzi partii": kolektyvy pedahohichnykh vyshiv Ukrainy v obrazakh shchodennia 1920-kh - pershoi polovyny 1960-kh rokiv ["The closest friends of the party": groups of pedagogical universities of Ukraine in the images of everyday life of the 1920s - first half of the 1960s]. Poltava, 658 p. [in Ukrainian].

7. Maiboroda, V. K. (1992). Vyshcha pedahohichna osvita v Ukraini : istoriia, dosvid, uroky (1917-1985 rr.) [Higher pedagogical education in Ukraine: history, experience, lessons $(1917$ - 1985)]. Kyiv, 196 p. [in Ukrainian].

8. Marusyk, T. V. (1999). Studentstvo Bukovyny pid tyskom stalinskykh represii (1945 - 1950-ti roky) [Students of Bukovina under the pressure of Stalinist repressions $(1945-1950)]$. Z arkhiviv VUChKHPU-NKVD-KHB, 1/2 (10/11), pp. 457-468. [in Ukrainian].

9. Marusyk, T. (2003). Chernivetskyi natsionalnyi universytet im. Yu. Fedkovycha [Yuri Fedkovych Chernivtsi National University]. Encyclopedia of the History of Ukraine: in 10 vols. Kyiv, Vol. 10, p. 502. [in Ukrainian].

10. Khomenko, N. M. (2010). Deiaki aspekty politychnykh nastroiv povoiennoho studentstva Ukrainy [Some aspects of the political mood of postwar students in Ukraine]. Scientific notes of Vinnytsya Mykhaylo Kotsyubynskiy State Pedagogical University. Series: History, 17, pp. 85-91. [in Ukrainian].

11. Struk, N. \& Matviichuk, O. (2005). Chernivetskyi natsionalnyi universytet imeni Yuriia Fedkovycha. Imena slavnykh uchasnykiv. Dovidkovo-biohrafichne vydannia [Yuri Fedkovych Chernivtsi National University. Names of glorious participants. Reference and biographical publication]. Kyiv, 145 p. [in Ukrainian].

12. Chernivetskyi universytet. $1875-1995$. Storinky istorii (1995). [Chernivtsi University. 1875-1995. Pages of History]. Chernivtsi, 116 p. [in Ukrainian].

Стаття надійшла до редакції 16.12.2020

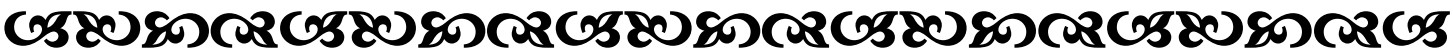

"Моральні яқості видатної особистості мають, можливо, більше значення для даного поқоління івсього ходу історії, ніж чисто інтелектуальні досягнення ".

Альберт Ейнштейн один з найвизначніших бізиків ХХ століття. Яауреат Нобелівської премії 1921 роқу

"Наші знання - це сума того, чого ми навчилися, й того, що ми забули".

Марія фон Ебнер-Ешенбах баронеса, австрійська письменниия

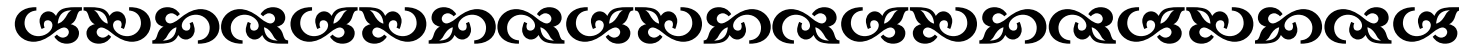

